\title{
International Labour Migration and its Implication in the APEC Region
}

\section{Rashid Amjad ${ }^{1}$}

\section{Introduction}

For those trying to find answers to the large number of unresolved and pressing issues resulting from international labour migration, the economies of APEC and their future development provide an area of very special interest. $\mathrm{APEC}^{2}$ includes amongst its member economies the world's two largest exporters of labour, namely Mexico and the Philippines, as well as the world's three largest destinations for permanent migration, namely, the United States, Canada and Australia. It includes economies, which both import as well as export labour and economies which have passed through the "turning point" or transition from a labour exporting to a labour importing country. It also includes the world's most populous economy, the People's Republic of China, which still exercises strict controls on labour migration, a situation, which could change dramatically in the foreseeable future. APEC, including as it does all the major economies in the fastest growing dynamic economic region in the world, is also ideally placed to provide an answer to the growing debate on whether globalisation will accelerate or slow down the present labour migratory pressures.

Yet, so far the issue of international labour migration has not figured prominently and indeed been somewhat played down in the deliberations of APEC. Although some recent initiatives ${ }^{3}$ have been taken to support and facilitate the mobility of qualified persons through sharing of labour market information on skills, wages and working conditions, among

\footnotetext{
${ }^{1}$ The author is Director of the ILO's South East Asia and the Pacific Multidisciplinary Advisory Team (ILO/SEAPAT) based in Manila. The views expressed in this article are his personal views and in no way reflect those of the ILO. The author would like to express his thanks to Mr. G. Battistela, Mr. W.D. Salter, Mr. G. Bhattacharya, Mr. M.I. Abella, Mr. P. Wickramasekara, Mr. A. Oberai and Mr. J. Connell for their assistance in the preparation of this paper. The assistance of the ILO Office, Mexico and ILO Multidisciplinary Team, Santiago, in providing information on Latin American countries is gratefully acknowledged. Thanks are also due to Ms. K. Landuyt for her assistance in the translation of documents from Spanish into English.

2 APEC members include Australia, Brunei Darusalam, Canada, Chile, the Peoples Republic of China, Hong Kong, Indonesia, Japan, Republic of Korea, Malaysia, Mexico, New Guinea, Philippines, Singapore, Chinese Taipei, Thailand and USA.

${ }^{3}$ See APEC Joint Ministerial Statement on Human Resource Development, Manila, 11 January 1996.
} 
others, the more critical issue of how governments can learn from each others' experiences and cooperate to manage and cope better with the legal and illegal flows of labour across international borders, including most importantly affording better protection to migrant workers, has not been directly examined. While APEC has rightly concentrated on human resources development issues, amongst others in order to provide and improve needed skills that would better facilitate the movements of capital, goods and services amongst member economies, the broader issue of how best to develop and utilise the common pool of all i.e., skilled and unskilled human resources, has not been taken up, even though it has been raised by some of the member economies.

The purpose of this paper is to identify some of the key issues which confront the member APEC economies arising from both the legal and illegal movements of labour across international boundaries, mainly to draw attention to the advantages that may accrue from discussing these issues in the APEC forum. In order to identify these key problems and issues the paper starts by presenting a brief review of existing labour flows within the APEC regions. There is also a brief discussion on some of the current explanations of how best to explain these flows and more important on the possible impact of globalisation and increasing trade liberalisation on the quantum and pace of the international movements of labour, in the APEC region.

\section{Trends in International Labour Migration ${ }^{4}$}

The fact that international migration issues figure prominently on the national agenda and preoccupy an increasing number of governments across the globe reflected the spread of labour migration across nations. While reliable estimates are difficult to establish, the ILO estimates that, if one disregards the situation in the successor states of the USSR, there are between 35 and 40 million persons economically active in a country other than their own in the world today, legally or illegally, and that they are accompanied by at least as many dependents (see Table-1).

No classification can neatly and comprehensively capture the variety of today's international labour migrants. Even the former distinctions between temporary migrants or contract workers and permanent settlers have become blurred. Unskilled or semi-skilled labour, including mainly farmers or peasants, who leave temporarily or permanently in search of wage-paid activities represent an important component of cross-border migrants. Skilled industrial or construction workers, who move individually

\footnotetext{
${ }^{4}$ This section is based on ILO (1996).
} 
or as part of an enterprise's labour force, constitute another sizeable element of present-day migrants. Highly qualified professionals and managers move much more than previously across the globe, both within and outside transnational enterprises. There is also a small but significant number of young persons, sponsored through government channels, for upgrading their skills in foreign enterprises, and who increasingly perform as normal workers, as well as entrepreneurs admitted by countries on the promise of citizenship if they bring along sufficient funds to generate employment for themselves and for others.

Broadly speaking, following these classifications, two kinds of international labour flows can be distinguished. The first are the movements of highly qualified professionals and managers across all countries of the world whether developed or developing. The second is the movement of mainly unskilled or semi-skilled workers who seek employment in lower rung jobs, mostly in high- and middle-income countries. The exceptions to this general pattern are countries with small populations (e.g. Brunei Darussaiam, the Arab States of the Persian Gulf and Malaysia), which are in need of migrants across the whole skill range, as well as the traditional immigration countries, United States, Australia and Canada, which still admit many migrants with skills in the middle ranges, though not necessarily on the basis of skills alone but for family reunification.

It is important, however, to point out that labour importing countries are not necessarily limited to those which are facing labour shortages or those with small population. Many developing countries have also become importers of labour well before they reach the level of full employment. This situation arises if the wage level in the developing country becomes higher than that of its neighbouring countries. This results in the inflow of labour, in many cases illegal, mainly from its surrounding countries where wage rates are lower, well before it has exhausted its own supply of underemployed or unemployed labour. Many developing countries in South Asia, Latin America and Africa find themselves in such a situation. There are also an increasing number of developing countries which find themselves in the situation of being both an importer and exporter of labour, well before they reach the "Lewisian turning point" of having exhausted their supplies of surplus labour.

\section{Labour Flows in the APEC Region}

In examining labour flows in the APEC region it is convenient to divide its different member economies into three broad categories. The first

\footnotetext{
${ }^{5}$ This section relies extensively on Stalker (1994) and in parts Amjad (1992).
} 
are the major destination economies for permanent migration, namely the United States, Canada and Australia to which we can add New Zealand, but keeping in mind that the United States also allows in large number of temporary migrants, mainly from Mexico, and that the distinction between permanent and temporary migration is becoming increasingly blurred. The second category includes economies which are dominated by intra-Asian flows of migrant workers. These can be further sub-divided into those fast growing economies which resulted in labour shortages and recourse to foreign workers, i.e., Japan, Republic of Korea, Taiwan/China, Hong Kong and Singapore and the emerging NIEs which are both importers and exporters of labour, namely Malaysia and Thailand and the major labour exporters in the region, namely the Philippines, Indonesia and the People's Republic of China. Also covered here are Brunei Darussalam and Papua New Guinea, although they clearly have their own distinct labour market needs. The third category covers labour movements within Latin America and the Caribbean. Although, Mexico and Chile are at present the only APEC members in this category, a brief description of dominant labour movements in Latin American countries is included to give a feel for the dynamic labour flows in this region, from which many economies may join APEC in the future.

As regards the flows of professional, management and higher skilled migrants which cover all economies, whether developed or developing, and whose number though small in elation to total migration flows is significant and increasing rapidly within the APEC region, this is dealt with separately in the next section.

\section{(i) The Major Economies of Permanent Settlement}

Starting in the 1960s far reaching changes introduced in their immigration policies had a major impact on the ethnic composition of immigrants to the United States, Canada, Australia and New Zealand. A significant proportion of those who now joined the migration stream to these countries were from the Asia-Pacific rim and mainly from APEC member economies.

The United States receives more immigrants than any other country - indeed almost more than all other countries put together. Total legal registered migration to the United States, according to Simon (1989), was 2.5 million between 1951-60, about 3.3 million during 1961-70, about 4.5 million during 1971-80 and 7.3 million during 1981-90. Of the 7.3 million migrants that came to the USA during 1981-90, three-fourth were from Latin America and Asia and nearly 3.2 million or about 45 per cent were from APEC economies. 
To form an idea of the arrivals from the APEC economies into the United States in 1992 for example of the 973,977 immigrants admitted, 364,639 or 37.4 per cent were from the APEC economies (Table-2). Of these, the major sending economies were Mexico $(213,802)$, the Philippines $(61,022)$, People's Republic of China $(38,907)$, Republic of Korea $(19,359)$. Taiwan/China $(16,344)$ and Canada $(15,205)$. Another 77,735 came from Viet Nam, and 26,191 from E1 Salvador on the Asia-Pacific rim. It is estimated that in 1990 of the total population of the USA of about 248.7 million, about 4.7 per cent or 11.6 million were of Mexican descent (Stalker, 1994, Table 11.2). Saith (1996) estimated that there are about 1.6 million Filipinos residing permanently in the USA in 1993 (p. 28).

In Canada, the other major destination of migrants from the AsiaPacific region, immigration has generally been more closely regulated than that to the United States. As in the United States significant changes were made in its immigration policy which lowered racial and ethnic barriers and removed almost all privileges reserved for European immigrants. According to Richmond (1991) of a total labour force of 11.9 million about 20 per cent were immigrants. During 1980-89) about 1.26 million immigrants landed in Canada of whom about 41 per cent were from countries in the Asia-Pacific region. Of the total 248,200 immigrants who entered Canada in 1992, the largest number came from Hong Kong (15.3 and 11.4). Those from the other APEC economies included the People's Republic of China ( 4.1 per cent), Taiwan/China and the United States (2.9 per cent each). The large number coming in from Hong Kong in recent years have been mainly investors and entrepreneurs looking for a safe area of settlement in advance of the reversion of Hong Kong to the People's Republic of china. In many cases, the investors move some of their households to Canada but still commute backwards and forwards to Hong Kong - a high-flying lifestyle which has caused them to be dubbed "astronauts" (Stalker, 1994, p. 179).

Australia, the third largest of the traditional countries of settlement, till the late 1960s with very few exceptions restricted immigration to Europeans only. This position was slightly altered in the 1960s when, in response mainly to sustained criticism by some Asian countries, the Australian Government admitted for permanent settlement a small number of highly qualified and professional workers from Asian countries. However, by the early 1970s the so-called "White Australia" policy was drastically changed, if not all but abolished. According to Appleyard (1988) this included the rapid increase in trade between Australia and Asian countries after the United Kingdom joined the EEC. Also following the Viet Nam war, there was increasing awareness that Australia's future, given its proximity to 
Asia, was closely linked to the socio-economic changes which took place in this region.

This change in attitude and policy was to shift the balance of immigration substantially in favour of Asia. During 1961-70 about 91,000 immigrants, or 6.5 per cent of the total, were from Asia and this increased to 207,000 or 23.1 per cent of the total during 1971-80 and had increased further to 40 per cent of total arrivals in the mid-1980s. In 1991-92 of the 107,391 settler arrivals almost 33 per cent were from APEC economies, namely from Hong Kong (12.5 per cent), New Zealand (6.7 per cent), Philippines (5.5 per cent), Taiwan/China (3.0 per cent), Malaysia (2.9 per cent) and the People's Republic of China (2.2 per cent), (Stalker, 1994, Tables 11.5 and 11.6). the other major source from the Asia-Pacific rim was Viet Nam (8.9 per cent). As in the case of Canada those from Hong Kong and Taiwan/China are business people in search of new opportunities, particularly in advance of the British colony's reversion to the People's Republic of china.

In the case of New Zealand the total number of migrants from APEC has been far less with about 10,000 migrants from Asia during 196170 (or 3.1 per cent of the total) and about 11,000 in $1971-80$ (or 5.5 per cent of the total). Many migrants into New Zealand have been from the neighbouring South Pacific countries. Also in recent years, there has been an increasing number of migrants from Hong Kong, mainly investors and entrepreneurs, although some of them have subsequently moved on to Australia. Between 1987 and 1992, 13,500 Hong Kong citizens were granted permanent residence in New Zealand and between 1990-1992, Hong Kong citizens were the largest single group of people approved for permanent residence. Between 1987-1992, about 34,000 people from the People's Republic of China, Hong Kong, Malaysia, Singapore and Taiwan/China gained permanent residence in New Zealand.

In respect of the problems and issues which international migration has raised in these countries on the top of the list, especially for the United States, is the problem of illegal migrants. The United States is especially vulnerable, with a 2000 mile border with Mexico, which is also the main source of illegal migrants (almost 90 per cent, if they follow the pattern of aliens apprehended by the Immigration and Naturalisation Services [INS]). Estimates of illegal migrants range from 1.9 to 4.5 million (Stalker, 1994 p. 146) and besides those crossing overland, the United States also has people arriving by boat, chiefly from the Caribean. A large number of these illegal migrants work as farm workers but they are also conspicuous in other sectors. An estimated 350,000 illegal immigrants in the United States work as domestic helps. To combat the rising number of illegal immigrants, the 
Government is increasing expenditure on border controls and denying access to welfare services to illegal immigrants.

Public opinion in these countries is also turning against immigration especially during periods of economic recession and high domestic unemployment. In both Canada and Australia, the "immigrant tap" has been turned on and off according to the economic circumstances. In Australia in 1992, a survey showed that one in three immigrants who had arrived in 1990 was unemployed and that for some ethnic groups, the jobless figure for recent arrivals was above 80 per cent. The Government therefore decided to cut immigration by more than 25 per cent in 1992-1993, the biggest cut in 25 years. However, the United States has not yet responded to the anti-immigrant lobby by reducing immigration levels and Canada envisaged moderate growth in its immigrant flows with around 250,000 settlers per year during the second half of the 1990s.

Another concern, especially in the context of globalisation, has been the need to attract highly skilled workers into these countries and especially the United States has taken steps to increase inflows of foreigners with "extraordinary ability" without the need for pre-arranged employment or nomination by a US employer.

\section{(ii) Intra-Asian Labour Migration}

Within the Asian economies of APEC according to Pang Eng Fong (1994) three streams of labour flows can be distinguished and each of these has expanded rapidly in the past decade. ${ }^{6}$ The first and fastest growing is between developing South-East Asia and the third among the North-east Asian economies.

The first stream involves the flow of mostly unskilled, legal and illegal workers from South-east (and South Asia) into North-east Asia, mainly Hong Kong, Taiwan/China and Japan and the flow of skilled and professional workers in the opposite direction.

The labour migration flows are much more complex amongst the South-east Asian economies. There is the flow of skilled and unskilled labour into Singapore from its ASEAN neighbours mainly Indonesia, Malaysia, the Philippines and Thailand. Also the emergence of growth triangles in the region, of which the most prominent is the Indonesia-Malaysia-Singapore Growth Triangle (IMS-GT) encompassing Malaysia's Johore state, Singapore and the Riau Islands of Indonesia, is expanding labour market links within

\footnotetext{
${ }^{6}$ The description of the flows that follows is also taken from Pang Eng Fong (1994).
} 
the South-east Asian neighbouring countries. Other major flows are from Indonesia and southern Thailand into Malaysia, from Myanmar into neighbouring Thailand and from various parts of South-east (and South) Asia into Brunei Darussalam.

The East Asian flows are equally complex. They include the flows into Japan of again both legal and illegal migrants (including as students and trainees) from the People's Republic of China, Hong Kong and Taiwan/ China but also from other Asian economies including the Philippines and South Asia. There is also a small flow of unskilled migrants into Hong Kong from the People's Republic of China and much larger reverse flows of professionals, managers and technicians into the Pearl River Delta area, where many labourintensive firms are relocated. There is also a mainly illegal flow of workers from the People's Republic of China into Taiwan/ China and the Republic of Korea, and a sizeable, short-term, unofficial flow of managers and professionals from Taiwan/China into the People's Republic of China.

In all the major labour-receiving Asian economies the major cause for these rapidly rising inflows has been the labour shortages that resulted from their fast growing economies which could not be met by a relatively slowly growing labour force. During the decade of the 1980s, the fast growing Asian NIEs grew at anywhere between 6 to 8 per cent annually, while Japan averaged 4.3 per cent or well above the average for the industrialised countries. (Abella, 1996). However, again as Pang Eng Fong (1994) points out, the size and timing of these flows has been vastly different. As distinct from Singapore and Malaysia, foreign labour inflows in Japan, the Republic of Korea and Taiwan/China, did not occur until many years after the labour shortages occurred. Japan which had first experienced labour shortages in the early 1970s, attracted illegal workers in large numbers only after 1986. Similarly the Republic of Korea and Taiwan/China achieved full employment in the late 1970s but the number of mainly illegal workers flowed into these countries a decade later.

It is also important to note that in the East Asian economies, mainly Japan, Republic of Korea and Taiwan/China, demand for migrant workers was fostered by emerging shortages of labour for certain occupations and sectors. These cover the hazardous jobs in construction, low-paying jobs in the services sectors and dirty or bottom-end jobs in manufacturing mainly in small and medium enterprises - the so called 3D jobs (dirty, demanding and dangerous). 
To quickly survey7 the international labour migration scene in the Asian region starting with the labour-receiving economies, the estimated number of foreign workers in Japan in 1993 was 1.32 million or 1.5 per cent of the workforce as compared to 696,000 in 1969. Of these, permanent resident Korean workers were 316,000, legal temporary professional $(95,000)$ trainees $(17,000)$, working students $(63,000)$, ethnic Japanese from South America (152,000 in 1992) and the rest were mainly illegal workers. In Hong Kong, the estimated stock of foreign workers in 1994 was 220,000 or 7.3 per cent of the workforce. Of these, about 50,000 were skilled and unskilled foreign workers employed as technicians and construction workers, and about 150,000 foreign maids, mostly Filipinos. The rest were foreign professionals. In the Republic of Korea, the 150,000 or so legal, illegal, and trainee workers accounted for less than one per cent of its 12 million strong workforce. According to Kang (1996), of these, there were 7,840 foreign professionals at the end of 1995, 41,000 trainees, and 102,000 illegal foreign workers, mostly ethnic Koreans from China, or nationals of Philippines, Bangladesh and Pakistan. The Republic of Korea has experienced one of the fastest migration transitions. Some 200,000 Koreans emigrated in 1982 and a decade later, there were about 100,000 legal and illegal foreign workers in the country. In Taiwan/China, again from no foreign workers in 1980, the number increased in 1995 to 220,000 mostly legal foreign workers, up from about 100,000 mostly illegal workers in 1989 , about 2 per cent of the country's labour force. In Singapore, there were in 1995 about 250,000 foreign workers or approximately 18 per cent of the workforce, up from 80,000 in 1980 ( 7.4 per cent of the workforce) and 21,000 in 1970 (or 3.2 per cent of the workforce).

Of the two Asian economies which are both importers and exporters of labour, in Malaysia in 1994, there were about 1.1 million foreign workers or about 15.5 per cent of the workforce. Of these, 563,000 were legal foreign workers and the rest were illegal. At the same time, there were about 250,000 Malaysians working legally and illegally abroad. Thailand is another fast growing economy that is simultaneously exporting and importing labour. There are an estimated 500,000 Thai workers employed abroad, including 25 per cent each in Saudi Arabia and Singapore. There are also about 500,000 foreign workers in Thailand - 200,000 professional expatriates, and 300,000 unskilled farm and construction workers from neighbouring countries.

\footnotetext{
${ }^{7}$ This survey is based primarily on Martin (1996), supplemented in parts by Abella (1996), Amjad (1996), Saith (1996), Nayyar (1991), Wickramasekara (1995), Connell (1996) and Hung (1996).
} 
Of the major labour exporters, the Philippines is the second largest country of emigration with an outflow of 719,602 overseas contract workers (OCWs) in 1994. Of these, land based OCWs were 565,226, up from 12,501 in 1975. The largest number of deployed land based OCWs was in Saudi Arabia $(215,631)$, followed by Hong Kong $(62,161)$, Japan $(54,879)$, Taiwan/China $(34,387)$ and UAE $(27,713)$. In 1994 , about 48 per cent of the total deployed OCWs were females but they accounted for almost 60 per cent of new hires. The majority of the new hires in 1994 were in the vulnerable occupations, with domestic help $(26.34$ per cent) and entertainers (18.17 per cent) accounting for almost half of total new hires. In such occupations, about 95 per cent were women. The estimated stock of Filipino workers abroad is estimated at around 4.2 million in 1995, of which permanent migrants (mainly in the United States) are estimated at 2 million, circulatory stocks in the range of 1.5 to 2.1 million and the rest are illegal migrants (mostly in Japan, Taiwan/China, Singapore and Malaysia). In terms of its labour market impact, if one restricts the figure to only land-based new hires, this would account for about 34.7 per cent of the total incremental active labour force for the country. In 1994, the remittance flows entering officially through the banking channel were US\$ 2.94 billion or 20 per cent of export earnings, and as much as 4 per cent of GDP in 1994. In recent years, there has been an important change in public thinking and policy perspective on migration's contribution to the development process following the hanging of a Filipino maid in Singapore in February 1995. Much higher priority is being assigned to increasing productive employment opportunities in the domestic economy and the gradual phasing out of female migration in the vulnerable categories.

In the case of Indonesia, the dimensions of the official labour flows and the financial flows associated with it are small, if not negligible, in the wider context of the national economy. In 1992, official labour outflows were 166,244 of which Saudi Arabia was the major destination (61.2 per cent) followed by Malaysia (20.1 per cent) Singapore (71 per cent) and Taiwan/China (3.1 per cent). However, a significant number leave Indonesia unofficially, mostly to nearby Malaysia where the men are employed on plantations and construction sites and the women are employed in factories and domestic service. It is estimated that the total number of Indonesian migrants in Malaysia may be as high as 750,000 with almost two-thirds as illegal workers (Martin, 1996). There are two striking attributes to international labour migration from Indonesia. Two-thirds of the migrants were women and there were no migrants with professional expertise. According to official estimates, total remittances in 1994-1995 were US\$ 344 million which is puzzling as the level of remittances per capita is only a fraction of what it is in other Asian labour-exporting countries. Most probably, a large proportion of remittances from illegal migrants in Malaysia 
came through unofficial channels. In Indonesia, the Government's pronouncements on migration indicate a shift in policy objectives by gradually phasing out migration of domestic helpers, mainly females, and moving towards the export of more highly skilled workers.

Overseas migration from the People's Republic of China, can, according to Hung (1996), be divided into four broad categories: labourexporting through contracted projects; direct recruitment (through domestic agents) by overseas employers; migration through relatives or friends in foreign countries and illegal migration. Under the first category, there were 225,578 workers at the end of 1994 (compared to 31,771 in 1982) working on projects with a contracted value of approximately US\$ 8 billion. Of the 100,000 students who went to study overseas between 1978 and 1989, only about 40 per cent returned home after graduation. In the 1990s, about 20,000 students go overseas each year and most undertake part-time or even full-time work especially in Japan and Australia. It is difficult to estimate the extent of illegal immigration from the People's Republic of China but Hung (1996) estimates it between 100,000 to 200,000 a year.

Turning to the last two economies in this region, Brunei Darussalam has a total labour force of about 112,000 from a population base of approximately 268,000. According to the 1991 population census, about 54,000 in the labour force are Brunei citizens, 7,000 are permanent residents and 45,000 are temporary and other residents employed by establishments in the public and private sector. Skilled foreign workers for both private and public sectors mainly came from Thailand, the Philippines and Indonesia. In the case of Papua New Guinea, localisation has already substantially reduced the amount of expatriate labour from around 30,000 at the time of the 1971 Census to around 9,000 at the start of 1982. Since then, decline has proceeded more slowly and the demand for foreign labour is more or less stable (Connell, 1996). Professionals and executive positions account for over 70 per cent of all work permit holders. As the European population has declined the number of Asians has increased. This increase has led to various objections to Asian migrant workers, mainly that members of their families take up other jobs and they also engage in commercial activities. Nevertheless, the total number of migrants has remained small and rare outside urban centers. More recently, Malaysian and Chinese workers are engaged in forestry employed by a Malaysian-based company.

In the context of intra-Asian labour migration, some of its distinct features and problems encountered can be summarised as follows:

(i) A significant feature of the rapid economic transformation of East and South-East Asian economies has been the accompanying growth 
of labour migration which increased from approximately just over a million (including long-term Korean residents in Japan and Indonesians in Malaysia) in the early 1980s, to over 3 million in the mid-1990s.

(ii) Although labour migration has grown rapidly in the region, only three economies namely, Malaysia, Singapore and Taiwan/China, have statutes which provide for the admission of unskilled foreign labour. Japan and the Republic of Korea both still have ambivalent policies on the importation of foreign labour.

(iii) State policies on the admission of foreign workers are primarily based on the idea of providing flexibility in the labour market. Foreign workers are seen as filling in the gaps and work permits are limited to short periods.

(iv) Mainly as a result of ambivalent migration policies, there has been a large increase in the numbers of illegal migrants, who find themselves increasingly exposed to all types of exploitative practices.

(v) There has been a growing feminisation of Asian labour migration, with more than half of migrants from the Philippines and Indonesia being women. According to a recent ILO study (Lim and Oishi, 1996), among the industries fuelling demand for Asian female workers "entertainment" is frequently a euphemism for prostitution. Outright prostitution is widespread and, in many cases, women contracted to work in legitimate jobs are then forced into prostitution. Women in any occupation who enter countries illegally or overstay their visas are subject to exploitation, but so-called entertainers are particularly vulnerable.

\section{Labour Flows in Latin America and Carribean Economies}

At present only Mexico and Chile are members of APEC amongst the Latin American economies. While most migration from mexico has been to the United States and this is discussed in more detail at the end of this section, migration from Chile has been mainly to neighbouring Argentina in the past and these flows have slowed down considerably in recent years as unemployment levels have grown in Argentina (nearing 20 per cent) and falling in Chile (at present, 5 per cent).

It may, however, be important to point out that Latin America and the Carribean (LAC) was in the past a region of significant immigration. The major flows into the region took place from 1870 to the 1960 s. it is 
estimated that the net migration to Latin America and the Carribean from the beginning of the 19th century to 1970 was 13.8 million mainly to Argentina, Brazil, Cuba, Uruguay, Venezuela, Mexico and Chile. Of these, 1.55 million were from Asia with significant flows from China, India and Japan totaling about 900,000. The largest flows were Italians moving to Argentina ( 3 million) but there were four other flows of over 1 million each: the Spanish to Argentina, and the Italians, Portuguese and from countries in Africa to Brazil.

The picture has changed dramatically in the post-1970 period. The region as a whole is losing people. Between 1976-85 net migration was -1.6 million compared to +1.8 million during 1950-64 (Stalker, 1994, p. 221). The most significant factor contributing to this change was the drop in immigration from outside the region to Argentina and the massive outflow from Mexico.

During the 1970s and 1980s most labour movements were within the region mainly into Argentina and Venezuela but this too slowed down and these countries are now experiencing much higher levels of emigration. Most of the immigration into Argentina was from Paraguay, Chile, Bolivia and Uruguay with men from these countries mostly found in construction and women in domestic services. More recently as Argentina begins to emerge from recession the Government plans to encourage immigration and believes it could take up to 300,000 East Europeans. It has identified Latvia, Estonia and Lithuania as recruiting grounds and is targeting middle-level skills.

In Venezuela too, starting in the 1960s most of the immigrants have come from the neighbouring countries, particularly Columbia, a large proportion of whom are illegal migrants. In 1981 of the total 1.07 million born foreign population, 508,166 were from Columbia and relatively much smaller number $(25,200)$ from Chile. In recent years these has also been a large influx of Brazilians. Also as in Argentina with the economic difficulties in the 1980s there was a slow down in net labour immigration but since 1990 as the economy has begun to recover the Government has begun to worry about skill shortages and has also set its sights on Eastern Europe.

In Ccntral America most of the recent flows have been of refugees rather than of labour migrants. In the 1960s many rural migrants moved into neighbouring countries including seasonal movements of Guatemalans to Mexico. Since the late 1970 s, political conflicts have uprooted some 2 million people and by 1980 some 10 per cent of Central Americans were living outside the countries of origin although as an uneasy peace returns to the region some of these are now beginning to return. 
The only significant migration flow between the Asian and Latin American economies is the result of the Japanese Government policies of attracting foreign nationals of Japanese descent by offering them long-term resident status, legal protection almost equal to that of Japanese-born citizens. Of the 1.1 million citizens of Japanese descent in Brazil and 80,000 or so in Peru many have been attracted by the prospect of work in Japan. In Sao Paolo between 1988 and 1991, the number of visas issued jumped from 8,602 to 61,500 and in Peru about 15 per cent of the Nikkei have gone through the formalities of emigration (Stalker, 1994, p. 251).

Mexico is the world's largest exporter of labour if we include both permanent and seasonal migration, most of which is to the United States. It also has a significant number of migrants working in the country mostly from Central America. According to the 1990 Census, the total resident population of Mexico was 85.5 million, the total number of immigrants was 383,000 and emigrants was 4.5 million. The latter number has increased from 576,000 in 1960 to 2.2 million in 1980. In addition, there are a significant number of seasonal workers in agriculture who migrate within Mexico as well as to the United States. Emigration to the United States increased from 159,000 in the $1950 \mathrm{~s}$, to 250,000 in the $1960 \mathrm{~s}, 1.4$ million in the $1970 \mathrm{~s}$ and 2.4 million in the 1980s. It is estimated that in 1990 , there were 4.5 million Mexicans living in the United States (Vasquez, 1993). In the United States, Mexican workers form a significant portion of the service sector in major cities (San Diego, Los Angeles, Chicago) and in the agricultural sector in California, Texas, Illinois and Florida (Murillo-Castano, 1984). Total remittances were estimated at US\$ 2.3 billion in 1989 and contributed 1.1 per cent to GDP and were 10 per cent of total export earnings in that year (Stalker, 1994, Table 8.2).

\section{Flows of Highly Skilled Labour}

Accompanying the high growth of foreign direct investment in the Asia-Pacific region has been the striking increase in the flow of professional, managerial and other skilled workers who have been accompanying investments by multinational companies throughout the region. In the earlier years most multinationals used their own expatriates to manage their operations but most countries increasingly rely on managerial and professional staff from within the region. Also as foreign investment flows from within the NIEs has gradually overtaken investment from Japan, a large number of professionals and highly skilled workers from Hong Kong, Republic of Korea, Taiwan/China and Singapore are working abroad. Companies from these countries are also more willing than Japan to employ third-country nationals. Also as job opportunities due to economic recession decreased in the developed countries in the region especially Australia and 
New Zealand, highly skilled labour from these countries have moved into the fast growing NIEs and other economies namely Malaysia, Indonesia, Thailand and more recently the Philippines.

Garnier (1996) provides estimates of the highly skilled labour and service providers in the Asian rim of the Asia-Pacific region (Table-3). Of the 87,000 professionals and managers from Hong Kong working abroad almost 50,000 are daily commuters to China's Southern Province. In early 1996, there were 110,000 expatriates working in Hong Kong coming from the United States $(36,000)$, Canada $(29,000)$, Japan $(24,200)$, Australia $(21,100)$ and the United Kingdom $(34,500)^{8}$ More recent estimates from Indonesia reported that in early 1995 these were almost 57,000 expatriate workers in the country with a wage bill of $\$ 2.5$ billion (Amjad, 1996). The example of Japan is also revealing. In 1993, about 273,000 Japanese workers resided abroad (with 25 per cent in Asia alone) working as the expatriate staff of the subsidiary of a Japanese multinational. In addition to this number, between 15,000 to 20,000 people are thought to have travelled abroad in the 1990s for short periods (of a few months at most) to provide some type of service.

Another interesting development is the steady flow of Asians (especially in the Republic of Korea, but also in other Asian-rim economies) who are returning from North America, Europe and Australia as new and equally well-paid opportunities open up in their own or neighbouring countries within the region.

\section{Impact of Globalisation on Labour Flows in the APEC Region}

The rapid pace of economic globalisation, especially in the APEC region, has been made possible by the process of liberalisation and the opening up of national economies to a far freer flow of goods and services. APEC members are committed to "open regionalism," designed to encourage greater openness throughout the global economy as well as in the region. Its goal of a free trade and open investment area was agreed upon by its member economies in November 1994 to be realised by 2010 for the developed economy members and by 2020 for the developing economy members. Progress within APEC towards regional trade and investment liberalisation is meant to supplement the multilateral trade system and to benefit all members of the global economy.

Economic globalisation at the present time has four main characteristics, namely the large and accelerating flows of foreign direct investment (FDI), large movement of portfolio capital, easier access to new

\footnotetext{
${ }^{8}$ Far Eastern Economic Review, 25 April 1996, p. 55.
} 
technology, and the freer movement of goods and services between countries. A priori, an acceleration in these flows and the opening of national economies should lead, at least in the medium and long-term future, to a reduction in labour flows, rather than its acceleration. This is primarily because these flows should result in the more efficient use of a country's economic resources reflecting its comparative advantage. It should imply that labour-scarce economies would specialise in more capital-intensive and skill-intensive production, while labour surplus economies would specialise in the production of labour-intensive goods. The freer movement of capital should help further exploit each country's comparative advantage and accelerate the trend of multinational corporations moving production from high wage to lower wage economies. This should mean that industries located in advanced or semiindustrialised countries which are dependent on the use of cheaper migrant labour, would now be under greater pressure to relocate production to low wage labour surplus economies.

This trend, however, of reducing the demand for labour in the labour scarce economies would need to take into account the growth of sectors and production processes in these economies which cannot be relocated to take advantage of low labour costs, and whose growth may increase due to higher overall rate of economic growth (as a result of globalisation). This would increase the demand for labour, at least in the short run, and for foreign workers for jobs in the services sector, construction, plantations and domestic services, including the so-called 3D jobs, mentioned earlier, which the nationals may not want to undertake. However, even in these sectors, in the long-term technological developments and movements of labour from the more labour-intensive industries should lead to a reduction in demand for foreign workers, except of course in the case of those jobs which nationals are not willing to undertake.

At the same time, globalisation would result, mainly due to increased inflows of FDI, but also as demand for a more highly skilled work force increases, in much greater flow of higher skilled labour, including professionals and managers across countries. This trend which has increased rapidly in recent years will be further accelerated, although over the long run trained nationals may gradually replace the expatriate work force especially where it would be cheaper to hire nationals rather than expatriates.

The more recent experience of the fast growing Asian economies, it would appear, has gone against the conventional economic wisdom that freer flows of goods between countries would substitute for the movements of labour between them. Indeed, it is now argued that based on this experience, the relationship between free trade regimes and migration flows is more often a complementary one and not one in which trade 
liberalisation substitutes for migration (OECD, 1994). To what extent should one accept this proposition?

In examining the experience of the East and South-East Asian economies, two important developments should be kept in mind. The first was the speed or pace of economic transformation as economies, especially the NIEs, achieved very high rates of economic growth for a sustained period of time (which had never been recorded before in economic history). The second was that this period of high economic growth coincided with changes in their demographic structures which led to a slowing down in the growth of the labour force and the emergence of an ageing population. At the same time, there were important changes in the attitudes towards certain kinds of work which the younger entrants into the workforce were not prepared to do. To this must also be added the factor that the surrounding labour surplus economies not only had workers willing to work abroad, but the recent experience in working in the Gulf countries where demand was declining, had prepared them to more aggressively seek employment abroad. Clearly, these factors combined together to lead to the dramatic increase in the use of foreign workers, estimated by Abella (1996), to have increased from 1 million to about 3 million in the short period of 10 to 12 years in the region.

The more important question therefore is whether migration is a passing phenomenon or a more permanent feature of development and growth in the East and South-East Asian region. Abella (1996) has argued that taking into account projected future growth in the region, which is expected to continue to be high, the slowing down in the growth of the labour force and increases in service sector employment in these economies will mean that there will be growing labour supply deficits in the coming decades in these countries in the region.

While there is reason to believe that these Asian economies will continue to be dependent upon the use of foreign labour, there is at the same time no reason to believe that there would be an appreciable increase in these flows. This is because one has already seen over the last decade the gradual movement of the more labour-intensive industries from the labourscarce to the more labour-abundant economies in the region. As globalisation and liberalisation intensifies and other economies in the region open up further, including Viet Nam and the People's Republic of China, the relocation of labour-intensive industries would further increase.

What is perhaps more challenging for the major labour importers is how they respond to changes in incremental labour demand in response to structural changes, especially the ageing of the population and growth of 
jobs in sectors in which the local population is not prepared to work. Here there will be two types of trade-offs. The first of allowing more organised labour immigration to provide services to their ageing population and improving the quality of old people's lives. The second is in relation to meeting demand of those sectors especially construction, essential services and small scale manufacturing where the local population is not willing to work. Here they can either translate "real demand" into officially allowing foreign workers into the country, or they can feign ignorance while fully knowing the existence of illegal workers. The way they decide on these choices will have a far reaching impact on the lives and conditions of work for foreign workers in these countries.

While clearly, more work is needed in this area to project labour supply and demand in the APEC region, some broad conclusions can be made:

(i) The first that the demand for higher skilled labour will increase and there will be greater movement of such labour in the region. Already, countries such as the United States and Japan are adjusting their laws in order to better tap into the emerging global labour market for highly qualified workers. Thus, the US Immigration Act of 1990 permits the annual settlement of 40,000 foreigners of "extraordinary ability" without the need for pre-arranged employment or nomination by a US employer. A further 40,000 immigrants of "exceptional ability" can be admitted where their services are required by US businesses. In the case of Japan, until 1990 , the country admitted 18 categories of foreigners with notable skills or business acumen, but it added ten categories in that year, as well as simplifying the formalities and speeding up the relevant procedures (ILO, 1996).

(ii) The second that most of the labour-receiving economies in East and South-East Asia will continue to be dependent on foreign labour and although it is difficult to project the additional demand for foreign workers in these countries, it will certainly be a major challenge for these economies to gradually adjust their economic structures to reflect their comparative advantage.

(iii) We have not yet separately examined the impact of globalisation on the more advanced economies of APEC as well as in the Latin American region. In the case of the former, as mentioned in (i) demand for higher skills will increase and in the case of Latin American economies as the recovery proceeds, there will be greater intra-regional movements as well as inflows of foreign migrants especially from the East European countries. 


\section{Key Issues in International Labour Migration in the APEC Region}

The review of major labour flows within the APEC region and the issues and problems that it has posed, for both the labour sending and the labour receiving countries, clearly points to the fact that while on the whole labour markets have functioned well, the regulatory and institutional framework has not always responded adequately to the challenges posed by international movements of labour, especially in recent years. Boutany and Papademetriou (1994) have suggested in a global context that "a crisis of legitimacy in migration policy has developed, caused primarily by quantitative and qualitative changes in migration and the way it is perceived." Yet, as Martin (1996) points out, while one is struck by the ability of societies and governments in Asia to lay the basis for rapid economic growth and economic integration through trade and investment, at the same time, "an outsider is also struck by the absence of transparent plans to deal with the long-term consequences of labour migration." (p. 9). Miller (1996) also points out that "International migration looms as a key factor affecting prospects for world order and disorder in the late 20th Century. Yet theories of international relations and world politics as well as studies of bilateral and regional relations have relatively little to say about international migration" (p. 1). He goes on to state that, "A key question for the next century is whether democratic ideals will foster regional integration which facilitates unproblematic labour migration" (p.9).

There is, however, a growing realisation that these issues cannot be tackled solely at the country level given the widespread involvement of the large number of countries in the migration stream. The need for a global approach to management of migration and the need for policy harmonisation is becoming all the more urgent. Also, it is now increasingly accepted that essential for the development of a successful approach is the need for a dialogue between the labour-receiving and labour-sending countries at bilateral, regional and global levels. There are also emerging instances of successful efforts at collaboration illustrated by greater harmonisation in their approach between the three main competitors (Australia, Canada and United States) for international labour skills through permanent migration, as well as notable instances of international cooperation between Latin American countries on refugee flows that have resulted in concrete steps like legalisation opportunities, through pacts and international agreements (Miller, 1996).

In this regard, it is also especially important to mention the ILO's standard setting activities and redress mechanisms to protect migrant workers and secure equality of treatment between nationals and nonnationals. The ILO Convention No. 97 (Migration for Employment, 1949) 
and Convention No. 143 (Migrant Workers, 1975), call upon governments to respect the basic human rights of all migrant workers, male and female, to prevent clandestine migration for employment and stop manpower trafficking activities. (For details of major ILO Conventions and Recommendations on migrant workers see Annex A). Topical as ILO Conventions on protecting migrant workers have been at various points of time, they have, however, enjoyed limited numbers of ratifications and most Member States that have ratified have been sending rather than receiving workers at the moment of ratification. This trend is confirmed by the International Convention on the Protection of the Rights of All Migrants and Members of Their Families, which was elaborated with the technical assistance of the ILO, and adopted by the United Nations General Assembly in 1990. However, only five countries have so far been willing to be bound by it - Egypt, Columbia, Morocco, the Philippines and Seychelles - all labour-sending countries.

While clearly there is a wide range of important and diverse issues arising from international labour migration which deserve high priority and immediate attention, this section focuses attention on only a limited number of issues which could play a part in the better management of migration flows in the future.

(i) There is a need for joint concerted action by both the labourreceiving and labour-sending countries to reduce the flows of illegal migration especially trafficking of illegal migrants by international criminal and smuggling syndicates. In many cases, migrants are passed along a chain which often involves a number of smugglers, safe houses, transit points and varied means of travel. To combat this trafficking, action is needed at the global as well as at the regional level and the combined efforts are required of both the laboursending and labour-receiving countries. APEC, with significant migration flows in the region, and with large numbers of illegal migrants, can play an important role in furthering these efforts.

(ii) Both the labour-receiving and labour-sending countries need to jointly address the problems and high costs of the labour-recruiting industry which exists in both these groups of countries. One of the major factors encouraging illegal migration is that in many cases the fees and costs (both official and unofficial) of securing employment abroad are so high that migrants find it more attractive to move through illegal channels which they perceive to be less costly (but which they later discover is not necessarily the case). Clearly better exchange of information on labour needs and mechanisms for recruitment between the labour-sending and labour-receiving 
countries would greatly facilitate the process. Also the question whether it is more efficient to conduct recruitment through government channels (i.e., government sponsored agencies) or private sector recruiting firms and the checks and balances that are needed in the form of official controls needs to be impartially examined and discussed in appropriate forums with the aim of devising more efficient and effective mechanism to facilitate legal cross-border flows at reasonable costs to the migrant. The need for developing a more efficient system becomes all the more important if APEC economies wish to facilitate the movement of higher skilled workers to meet shortages and surpluses (see vi).

(iii) There is a need for many of the labour-receiving economies in the APEC region, which at present have a rather ambivalent policy, to develop more transparent plans to deal with foreign workers. Many countries which at present tacitly approve illegal migration to meet labour shortages need to take a more realistic attitude and take necessary steps to ensure that "real demand" for imported labour is met through legal channels which affords full protection to the migrants and recognises their genuine rights. There is much that countries can learn in this regard from each others' experiences, including policies to further integration of migrants into the domestic economy. In this context, many APEC economies need to remember Max Frisch's summary of the European experience - we asked for workers, we got people instead - and fact up to the reality that some of the migrants will inevitably settle and the need for them to plan for a smooth integration.

(iv) There is little doubt that the highest priority must be given to combating the exploitation and physical, sexual and other abuse of female migrant workers, especially given the increasing feminisation of labour migration flows in the Asian region. This would require action at the national, regional and international level as well as by the migrants themselves in the host countries. Forums such as APEC could play an important role by increasing awareness and developing measures for action and protection to combat such exploitation including encouraging member economies to adopt and respect International Labour Standards, to protect the rights of migrant workers.

(v) There is a need to initiate steps that afford much greater social protection to migrants especially equality of treatment in qualifying for social security benefits and the removal of territorial restrictions in this regard. The adoption and respect for ILO Convention No. 118 [Equality of Treatment (Social Security) Convention, 1962] and 
Convention No. 157 (Maintenance of Social Security Rights Convention, 1982) could play an important part in achieving this goal.

(vi) There is a need to ensure timely and regular exchange of information on shortages and surpluses for higher level skills and measures to facilitate movement of such skilled labour. This will greatly assist in facilitating the growth of investment and trade flows amongst the member APEC economies. Some important steps in this regard have already been initiated by APEC under its Working Group on human resources development.

(vii) There is a need to develop strategies and policies which lead to maximising the development benefits of overseas migration for both the labour-sending economy and the individual migrant, while at the same time minimising to the extent possible its adverse effects on the economy. These policies should include measures to facilitate the productive reabsorption of return migrants. Again, APEC members could learn from each others' experience in dealing with macro-economic and sectoral issues arising from international migration and the flow of remittances into the national economy.

\section{Conclusion}

APEC has already initiated steps to better monitor labour markets in its member economies which would improve the functioning of labour markets including facilitating movements of highly skilled labour within APEC. There is little doubt that APEC can play a leading role in extending the scope of global economic liberalisation in the most dynamic economic region in the world. At the same time, while reaping the benefits of faster growth that globalisation and liberalisation will make possible, and indeed to assist in ensuring their sustainability, APEC must also respond with imaginative solutions to the challenges and pressures that arise in this process. The issue of international labour migration definitely poses one of these challenges on which different perceptions exist, but APEC can meaningfully contribute in the quest for a more orderly and humane management of international labour migration. A start could be made by extending further its work on analysis of labour market issues to deal with some of the issues proposed above. 


\section{Annex $A$}

The Migration for Employment Convention (Revised) 1949 (No. 97) and the accompanying Migration for Employment Recommendation (Revised) 1949 (No. 86) are milestones in international migration legislation and put emphasis on inter alia, medical services, equality of treatment in respect of remuneration and membership of trade unions, the provision of free public employment services and the supervision of employers' or private agencies' recruitment, introduction and placement operations. The Equality of Treatment (Social Security) Convention 1962 (No. 118) addressed problems faced by migrant workers and their families due to difficulties in qualifying for certain be3nefits and the territorial restriction of benefits. Part I of the Migrant Workers (Supplementary Provisions) Convention 1975 (No. 143) constitutes the international community's first attempt to tackle the questions of irregular migration movements and illegal employment that became acute at the beginning of the 1970s. Part II seeks to promote greater equality of opportunity and treatment of lawful migrants with respect to employment and occupation. The Maintenance of Social Security Rights Convention 1982 (No. 157) represents a comprehensive attempt to cover migrant workers and their family members, particularly those who, due to the temporariness of their moves and employment, may not be able to benefit from acquired rights or rights in the course of acquisition.

Table-1: Estimate of Non-nationals by Region in 1990 (in millions)

\begin{tabular}{lccc}
\hline \multicolumn{1}{c}{ Region } & $\begin{array}{c}\text { Economically } \\
\text { Active }\end{array}$ & Dependents & Total \\
\hline Africa & $5-6$ & $11-14$ & $16-20$ \\
Americas, North & 7 & $8-10$ & $15-17$ \\
Americas, Central and South & $3-5$ & $4-7$ & $7-12$ \\
Asia, South, South East and & $1-3$ & $3-4$ & $4-7$ \\
East & 6 & $2-3$ & $8-9$ \\
Asia, West (Arab States) & 8 & 12 & 20 \\
Europe (excluding the USSR) & $\mathbf{3 0 - 3 5}$ & $\mathbf{4 0 - 5 0}$ & $\mathbf{7 0 - 8 5}$ \\
\hline Overall Totals & & &
\end{tabular}

Source: ILO (1996) 
Table-2: United States of America:

Immigrants Admitted from Top Eifteen Countries of Birth, Fiscal Year 1992

\begin{tabular}{lrrrrrr}
\hline & \multicolumn{2}{c}{ Total } & \multicolumn{2}{c}{ Non-legalisation } & \multicolumn{2}{c}{ IRCA legalisation } \\
\hline Country of birth & Number & Percent & Number & Percent & Number & Percent \\
\hline All countries & 973,977 & 100,0 & 810,635 & 100.0 & 163,342 & 100.0 \\
(1) Mexico & 213,802 & 22.0 & 91,332 & 11.3 & 122,470 & 75.0 \\
(2) Viet Nam & 77,735 & 8.0 & 77,728 & 9.6 & 7 & $\mathrm{Z}$ \\
(3) Philippines & 61,022 & 6.3 & 59,179 & 7.3 & 1,843 & 1.1 \\
(4) Soviet Union & 43,614 & 4.5 & 43,590 & 5.4 & 24 & $\mathrm{Z}$ \\
(5) Dominican & 41,969 & 4.3 & 40,840 & 5.0 & 1,129 & 0.7 \\
$\quad$ Republic & & & & & & \\
(6) People's & 38,907 & 4.0 & 38,735 & 4.8 & 172 & 0.1 \\
$\quad$ Republic of & & & & & & \\
$\quad$ China & & & & & & \\
(7) India & 36,755 & 3.8 & 34,629 & 4.3 & 2,126 & 1.3 \\
(8) E1 Salvador & 26,191 & 2.7 & 21,110 & 2.6 & 5,081 & 3.1 \\
(9) Poland & 25,504 & 2.6 & 24,837 & 3.1 & 667 & 0.4 \\
(10) United & 19,973 & 2.1 & 19,757 & 2.4 & 216 & 0.1 \\
$\quad$ Kingdom & & & & & & \\
(11) Republic of & 19,359 & 2.0 & 18,983 & 2.3 & 376 & 0.2 \\
$\quad$ Korea & & & & & & \\
(12) Jamaica & 18,915 & 1.9 & 16,820 & 2.1 & 2,095 & 1.3 \\
(13) Taiwan/China & 16,344 & 1.7 & 16,232 & 2.0 & 112 & 0.1 \\
(14) Canada & 15,205 & 1.6 & 14,958 & 1.8 & 247 & 0.2 \\
(15) Iran & 13,233 & 1.4 & 12,808 & 1.6 & 425 & 0.3 \\
Others & 305,449 & 31.4 & 279,097 & 34.4 & 26,352 & 16.1 \\
\hline & & & & & & \\
\hline
\end{tabular}

Source: Immigration and Naturalization Service, 1992. 
Table-3: Estimate of the Movements of Highly Skilled Labour and Service Providers in the Asian Pacific Region

\begin{tabular}{|c|c|c|c|c|c|c|c|c|c|}
\hline $\begin{array}{c}\text { Country } \\
\text { or } \\
\end{array}$ & Natio & nals & Abr & oad & Tempo & orary res & $\begin{array}{l}\text { sidence o } \\
\text { foreigner }\end{array}$ & $\begin{array}{l}\text { f highly } \\
\text { os }\end{array}$ & skilled \\
\hline Region & $\begin{array}{l}\text { Business } \\
\text { Travels }\end{array}$ & 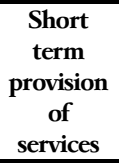 & Expatriate & $\begin{array}{c}\text { Long- } \\
\text { term } \\
\text { highly } \\
\text { skilled } \\
\text { migrants } \\
\end{array}$ & $\begin{array}{c}\text { Business } \\
\text { travels }\end{array}$ & 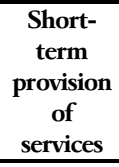 & $\begin{array}{c}\text { New entry } \\
\text { of } \\
\text { expatriate } \\
s\end{array}$ & $\begin{array}{c}\text { Posted } \\
\text { expatriate } \\
s\end{array}$ & $\begin{array}{c}\text { Year } \\
1993-94\end{array}$ \\
\hline Australia & - & - & 35,000 & $\begin{array}{l}35,000 \\
\text { (Hong } \\
\text { Kong) }\end{array}$ & 202,000 & 13,000 & - & 12,500 & - \\
\hline $\begin{array}{l}\text { People's } \\
\text { Republic of } \\
\text { China }\end{array}$ & - & - & $\begin{array}{c}10,000 \\
\text { (construc } \\
\text {-tion } \\
\text { sector) }\end{array}$ & - & - & - & - & - & Recently \\
\hline Hong Kong & - & - & 87,000 & 36,000 & - & - & 6,500 & 50,000 & 1991 \\
\hline Japan & $\begin{array}{l}1,025,000 \\
(1988 / 89\end{array}$ & $5,000(?)$ & 85,000 & - & - & - & 21,000 & 64,000 & 1992 \\
\hline $\begin{array}{l}\text { South } \\
\text { Korea }\end{array}$ & $\begin{array}{r}315,000 \\
(1988 / 89)\end{array}$ & - & 87,000 & - & - & - & 18,260 & - & 1992 \\
\hline Indonesia & - & - & 20,000 & - & - & - & - & 52,000 & 1993 \\
\hline Malaysia & - & - & 1,000 & 40,000 & - & - & 8,200 & 61,300 & 1993 \\
\hline Philippines & 60,000 & 40,000 & 10,000 & - & - & - & - & - & 1993 \\
\hline Singapore & - & - & 10,000 & 20,000 & - & - & 7,500 & 50,000 & 1994 \\
\hline $\begin{array}{l}\text { Taiwan/ } \\
\text { China }\end{array}$ & - & - & 120,000 & - & - & - & - & - & 1992 \\
\hline Thailand & - & - & - & - & - & - & 36,600 & - & - \\
\hline
\end{tabular}

Source: Garnier (1996). 
40 The Lahore Journal of Economics, Vol.1, No.1

\section{References}

Abella, Manolo, I., 1996, Sustainability of Labour Migration in East and Southeast Asia, Mimeo, ILO Geneva.

Amjad, Rashid, 1989, To the Gulf and Back: Studies on the Economic Impact of International Labour Migration, ILO/ARTEP, New Delhi.

Amjad, Rashid, 1992, "The Dynamics of Asian Labour Migration," in JIL (Japan Institute of Labour), Present Issues of International Migration: How can the Sending and Receiving Countries Cooperate? Proceedings of the 1992 Asian Regional Conference on Industrial Relations, Tokyo.

Amjad, Rashid, 1996, "Philippines and Indonesia: On the Way to a Migration Transition?" paper presented at the Conference on "The Dynamics of Labour Migration in Asia," 6-8 March 1996, Nihon University, Tokyo.

Appleyard, Regional, T., 1988, "International Migration in Asia and the Pacific," in Appleyard, R.T. et. International Migration Today. Volume 1: Trends and Prospects, UNESCO/University of Western Australia, Paris.

Boutany, Y.M. and D. Papademetriou, 1994, "Typology, Evolution and Performance of Main Migration System," in OECD, Migration and Development: New Partnership for Cooperation, Paris.

Connell, John, 1996, Papua New Guinea: The Struggle for Development, Routledge, London (Forthcoming).

Garnier, P., 1996, "Service Providers: Growing Dimensions of Highly Skilled Labour in Asia," paper presented at the Conference on "The Dynamics of Labour Migration in Asia," 6-8 March 1996, Nihon University, Tokyo.

Huang, Yiping, 1996, "Emigration Pressure in China: Changing Structure and Growth Potential," ILO/EASMAT, Bangkok (Mimeo).

International Labour Office, 1996, "International Migration and Migrant Workers," G.B. 265/ESP/2, Governing Body, Committee on Employment and Social Policy, Geneva (March). 
Kang, S.D., 1996, "Globalization of Labour Market also in South Korea?," paper presented at the Conference on "The Dynamics of Labour Migration in Asia," 6-8 March 1996, Nihon University, Tokyo.

Lattes, Recchini de and Alfredo Lattes, 1994, "International Migration in Latin America: Patters, Determinants and Policies" in International Migration: Regional Process and Responses, United Nations Economic Commission for Europe/United Nations Population Fund, 1994.

Lim, Lin Lean and OISHI, Nana, 1996, International Labour migration of Asian Women: Distinctive Characteristics and Policy Concerns, ILO Geneva.

Martin, P., 1996, "Leading Issues in Asian Labour Migration," paper presented at the Conference on "The Dynamics of Labour Migration in Asia," 6-8 March 1996, Nihon University, Tokyo.

Miller, M., 1996, "Prospects for Cooperative Management of International Migration in the 21st Century, paper presented at the Conference on "The Dynamics of Labour Migration in Asia," 6-8 March 1996, Nihon University, Tokyo.

Murillo-Castano, Gabrie1, 1984, Migrant Workers in the Americas: A Comparative Study of Migration between Columbia and Venezuela and between Mexico and the United States, Monograph Series 13, Center for U.S. Mexican Studies, University of California, San Diego.

Nayyar, Deepak, 1996, "International Migration and Structural Change in Indonesia," ILO/SEAPAT, Manila (Draft).

Pang Eng Fong, 1994, "Labour Migration, Economic Development and Regionalisation in the Pacific Asian Region, in OECD, Migration and Development: New Partnership for Cooperation, Paris.

Richmond, Anthony H., 1991, "Foreign-Born Labour in Canada: Past Patterns, Emerging Trends and Implications," Regional Development Dialogue, Vo1. 12, No. 3, Autumn 1991, UNCRD, Nagoya.

Saith, Ashwani, 1996, "Emigration Pressures and Structural Change in the Philippines," ILO/SEAPAT, Manila (Draft).

Stalker, Peter, 1994, The Work of Strangers: A Survey of International Labour Migration, ILO Geneva. 
42 The Lahore Journal of Economics, Vol.1, No.1

Vasquez, Rodolfo Corono, 1993, "Migration permanente interstatale international, 1950-1990," in Commercio Exterior, Mexican National Bank of Foreign Trade, Mexico.

Wickramasekara, Piyasiri, 1995, Recent Trends in Temporary Labour Migration in Asia, ILO/EASMAT, Bangkok.

Widgren, J., 1996, "International Co-ordination of Policies Against Alien Smuggling," paper presented at the Conference on "The Dynamics of Labour Migration in Asia," 6-8 March 1996, Nihon University, Tokyo. 